\title{
Study on the Role of Football in College Physical Education Teaching and Training
}

\author{
Feng Du \\ Xi 'an Peihua College, Xi'an, Shaanxi, 710125
}

Keywords: Football, College Physical Education, Training Science

\begin{abstract}
The development of modern football is characterized by the attack and defense of the two sides around the competition for the focus on the ball to focus on the goal to start the technical and tactical fitness and intelligence contest, and this feature is more in line with the training of college students in the attitude, ability, intelligence, The content and conditions of comprehensive development of the content of competition, it fully has to promote the quality of students comprehensive and fully developed content and conditions, compared with other sports, has its unique educational role and function, this, focusing on educators and society Long-term development requirements, combined with the physical and mental conditions of contemporary college students and the needs of football education and training, talk about the role of football in college sports.
\end{abstract}

\section{Introduction}

Football is a sporty competition with more tactical and tactical changes. In the training or competition, the athlete can use the action, such as running, jumping or collision, and reasonable tactics to carry out the intense contest. Football as the world's first movement, with a wide range of audiences, especially college students, in the prime of age to be able to experience the fierce confrontation in the passion of youth. Football is a need for endurance exercise, the human body will have a certain stimulus, has the role of improving the human body function, in the sports by the majority of young people love. The teaching and training of football in colleges and universities mainly aim at cultivating tactics and improving practical ability, and the methods and means of training are not the same. The technique and tactics of football are more difficult than other sports, it is the movement to dominate and control the ball, but also because it is so many people love to win. The development of football in colleges and universities, on the one hand to improve the physical and athletic quality of students, on the other hand can also promote the strengthening of the central nervous system, so that students' ideology and health level have been improved.

\section{The Role of Football in the Process of Cultivating Talents in Colleges}

Modern education strengthens the cultivation of students' abilities. In the traditional educational ideas and models, more emphasis on the teaching and interpretation of knowledge, while ignoring the cultivation of students' ability, students only store the knowledge of the warehouse; can not play their own creativity and potential. And today's education attaches more importance to the cultivation of students' ability, through a series of programs to develop a creative talent. Imaginative abundance; It has a keen observation; It has the ability to solve the problem independently; strong thinking ability; The creative ability of the people; Have a strong and unyielding practical ability. College football teaching and training to join the football, to a certain extent, can promote the development of the above capabilities, the majority of physical education teachers as long as good at the advantages of football, and constantly tap the potential of students, will be able to play better football To the role.

Cultivate students' creative thinking. Football practice and teaching, can be said to reflect the best place to create students, students according to the rules of football and space constraints, better 
reflect its creativity. As we all know, there are 22 athletes on the football field, they are interrelated and cooperate with each other, every second may create a different miracle, which are fully demonstrated football has a wealth of creative charm. Creative performance in many aspects such as: the mobilization of athletes, the players running on the field, etc., no matter what part of the deep creative spirit, so that students in the teaching and training process, do not have to suppress their own talent, as far as possible To create a miracle.

Exercise the way students think. Modern society requires talent to have a scientific way of thinking and superb understanding of the ability of students to survive and develop are built on top of this. Football contains a certain dialectical thinking and thinking based on the content. A person's dialectical thinking determines his understanding of football and the level of movement, and China's football and the level of world football, there is an important reason for the gap between the understanding of football superficial and rigid understanding. Soccer field on the occurrence of all things change, there is a certain relationship between them, but also naturally from which to find the answer. Therefore, colleges and universities should be through the strengthening of students 'knowledge of football knowledge to gradually adjust to develop a holistic, universal contact with the concept of understanding of things to increase students' understanding of the depth and breadth of things, rather than stay in the superficial level, thus Promote the improvement and development of students' self-personality.

Improve the psychological ability of students. Today's social market competitiveness is very great, as a college student must have a strong psychological endurance, the future can better face the community. However, the current college students do not have a strong ability to adapt, but also the social pressure is not the corresponding ability to bear, when the face of the measures or failure is prone to psychological shadow, the performance of the overwhelmed, there may be confused or weary Emotions, the development of students is extremely unfavorable. Soccer is a relatively competitive sports in the sports project, in the football field, the only goal is to win the competition, but at the same time also to the football players to bring some psychological pressure. In addition, the game on many changes and the audience, the referee and other reasons will directly affect the player's psychology, which requires football players must have a strong psychological affordability and stability. Modern football after a long period of development has been a level of improvement, in this high case, the requirements of football players is no longer confined to physical fitness and football technology, in addition to the need for athletes with A certain tactical quality and stability of the psychological quality. College students in the classroom teaching of football to join, you can make students in the process of growth, psychological compression ability, in the future into the community will be able to calmly face difficulties and courageous forward.

\section{Football Teachers in Football Teaching}

In the implementation of football teaching and training, teachers should be based on teaching objects and teaching objectives to select the content and methods, mining and innovation targeted teaching and training mode, so that students in the physical and psychological impact and role, so that teaching and training To the desired effect.

Combined with the characteristics and functions of football, in arranging teaching should pay attention to the ability of students to develop, technical skills, tactical ability, collaboration with the ability to organize the ability to match the actual combat. But the core issue is to seize the main objectives and problems, that is, through the practice of the game to cultivate athletes integrated ability, must not focus on a training method and ignore other methods, to deal with the relationship between them in order to receive good teaching With training effect.

In the teaching and training process, teachers should pay attention to adjust the psychological state of the players to stimulate their enthusiasm and enthusiasm for training. Especially attention to the optimization of the psychological state of the players, so you can mobilize the sports power, pleasure, etc., so that the cognitive similarity, the situation is compatible, psychological interaction, the mood in a moderate state of excitement. This requires teachers to be good at regulating the atmosphere or create a relaxed training environment, so that athletes feel comfortable, full of 
emotion, strong training, which will help improve the quality of teaching and training.

In order to stimulate the students' interest in learning and practice, so that students master the advanced football theory knowledge, skills and methods, cutting-edge information, football teachers should learn and good use of advanced technical means for teaching and training. Therefore, teachers should master the use of computer, multimedia, camera and other tools to ensure scientific, accurate and timely knowledge of football knowledge and information to scientifically guide teaching and training, teaching and training level and the students' football ability Constantly improve, keep up with the pace of the times.

\section{Improve the Effectiveness of Football in College Sports and Training Measures}

Rich football teaching content. In the football of college, should take full account of the feelings of students, according to the psychological quality of students and students to arrange their own different courses. Teachers can be based on the student's gender, personality, etc. to be divided into several groups to group the way to teaching, according to different forms of teaching to prepare a different teaching content, so that students in the physical and mental environment to learn, willing to take the initiative To join the football, so as to achieve the purpose of improving the overall quality of students.

Enhance the concept of football teaching. Physical education can, to a certain extent, achieve the perfect unity of human thought and body, including human purpose, motive and thinking. The current college physical education is to cultivate the physical quality of students and develop good habits of students, at this stage, contribute to the physical and mental development of students and the development of sports spirit. Therefore, the college football teaching should be fully combined with the interest of students to carry out, from the students' growth characteristics and interests of the college sports teaching model of continuous reform and innovation, the football classroom has become more substantial and rich, So as to mobilize the enthusiasm and interest of students, so that students feel the joy and passion of football.

Pay attention to the development of students' personality. The traditional football teaching is generally concerned about the cultivation of student football technology, while ignoring the students' personality development. Therefore, in the future football teaching and training to strengthen the student-centered teaching philosophy, teachers in this only play a guiding role. In addition, in the teaching and training process, should be fully into the moral knowledge to them, to guide students to form a good team spirit and a serious and responsible attitude. So that teachers in the football classroom not only play the role of education and skills to teach, but also to develop students to develop a sound personality and cultivate a certain degree of innovation. Improve the overall level of the players, so that players can have excellent overall quality of football.

\section{Conclusion}

To strengthen the physical education in colleges and universities, we must deeply understand and tap the profound connotation of teaching content, especially by the majority of students favorite football, to fully tap its educational function and value and effectively play its role, need to deepen the football The understanding and understanding. Football has its profound connotation and rich content in the biological level, the cultural level, the social level and the education level. It can exert a great function and function to the college students' quality education and cultivate modern talents in college physical education. Can promote the development of physical education in colleges and universities to the breadth and depth of development, and promote the combination of biological and humanistic goals of football education goals in order to achieve the short-term and long-term unity of educational goals. Football is not only the content and means of sports, but also a powerful weapon to cultivate new talents, it should be more practical role in the socialization of college students. The future of the world competition is the talent competition, only to cultivate college students both lofty ideals, but also a wealth of knowledge and strong physique, in order to assume the cause of future business and national prosperity, it must deepen the understanding of football, 
mining Its function and value, at the same time teachers should have innovative consciousness and as a good use of football teaching materials, so that in the cultivation of high-quality personnel in college physical education play a full role.

\section{References}

[1] Wang Housheng. Analysis of football rules change on the impact of football [J].Journal of Jiamusi Vocational College, 2017 (05)

[2] Meng Xianghua. Journal of Chifeng University [J]. Journal of Chifeng University, 2017 (14)

[3] Liu Bo. Soccer technology in the action of the principle of physics analysis [J]. Middle school physics teaching reference, 2017 (14)

[4] Yao Dawei. Thoughts on the development of Chinese football [J]. Theoretical observation, 2016 (12)

[5] Deng Xiao, Li Bank. The role of ideas in the development of Chinese football [J]. Sichuan Sports Science, 2016 (02) 